\title{
SLOVAKIA 1939 - 1945: STATEHOOD AND INTERNATIONAL RECOGNITION (DE IURE OR DE FACTO STATEHOOD?)
}

\author{
Michal Považan ${ }^{1}$ \\ Comenius University, Bratislava
}

\begin{abstract}
:
The world is entering a new phase in its international relations. In Eastern Europe new political entities have emerged. The article deals with the case of Slovakia in the period 1939-1945, an example of a de facto State that emerged during a time of instability in Europe. Slovakia 1939-1945 held many characteristics of a de iure State such as a wide international recognition. From a formal point of view it could thus be described as a de iure State, however, the article shows that it is not possible to characterise it in this way and slightly amends the criteria for accepting de facto States. The case of Slovakia 1939 1945 shows how vulnerable small States can become and how quickly recognition can be granted as well as withdrawn.
\end{abstract}

Keywords: Slovakia, international law, continuity, de facto State, Czechoslovakia, WWII, recognition.

\section{Resumen:}

El mundo ha entrado en una nueva fase en las relaciones internacionales y han surgido nuevas entidades políticas en el Este de Europa. El artículo se centra en el caso de Eslovaquia durante el período 19391945, un ejemplo de un Estado de facto, que surgió en una época de inestabilidad en Europa. Eslovaquia en el período 1939-1945 tenía muchas características de un Estado de iure, como un amplio reconocimiento internacional. Desde un punto de vista formal podía ser descrito como un Estado de iure, sin embargo el artículo muestra que no se le puede caracterizar de esta forma y enmienda un poco los criterios para la aceptación de los Estados de facto. El caso de Eslovaquia en el período 1939-1945 muestra lo vulnerables que pueden llegar a ser los Estados pequeños y cómo el reconocimiento puede concederse con rapidez y también retirarse.

Palabras clave: Eslovaquia, derecho internacional, continuidad, Estado de facto, Checoslovaquia, Segunda Guerra Mundial, reconocimiento.

Copyright @ UNISCI, 2014.

Las opiniones expresadas en estos artículos son propias de sus autores, y no reflejan necesariamente la opinión de UNISCI. The views expressed in these articles are those of the authors, and do not necessarily reflect the views of UNISCI.

\footnotetext{
${ }^{1}$ Michal Považan, Phd, teaches in the Comenius University in Bratislava, Law Faculty. His main research area is Legal history regarding international public and constitutional law in Central and Eastern Europe Address: Univerzita Komenského v Bratislave, Právnická fakulta Šafárikovo námestie č. 6. 81000 Bratislava 1 Slovenská republika.

Email: Michal.Povazan@flaw.uniba.sk.
} 


\section{Introduction}

Based on the results of WWII, a new international order was built. This order survived with some changes and modifications almost until the end of the 20th century. With the break-out of the Soviet Union, one of central pillar of the international system, the system itself started to fall apart. One of the features, not seen before, was the emergence of a growing number of political entities with some characteristics of statehood and with effective control over some of its territory, but not recognised as States by international community or by the parent State and therefore living in bigger or lesser isolation.

The danger of dissolution of States, always remained in ineffective States beyond the Euro-Atlantic world. Now, this phenomenon has moved to the very heart of the western world.

A similar situation existed in the western world before and during WWII. The instability of the international order during these times and the rapid development of international relations, often in contradiction to international law, resembles contemporary situation.

The emergence of small States against the will of their parent States, an instable situation, problems with international recognition, the interference of powers in these processes and the internal situation of new States, were the incentives which motivated the author to focus on a not very well-known case in the history of international relations and international law: Slovakia 1939 - 1945. Its short history is interesting from the perspective of State recognition, the status of de iure or de facto State and as for the prospects of survival of a new small nation State created in turbulent times.

The article deals mostly with legal concepts of international law and the contemporary perception of Slovakia 1939-1945 as a territory of the former Czechoslovakia. From the perspective of Czechoslovakia and its successive States, the Slovak and Czech republics, Slovakia 1939-1945 legally did not exist. It might have been a de facto State, for as de iure, Czechoslovakia is considered as having existed between 1918 and 1992 without interruption, and that despite the fact that the Slovak entity received wide international recognition. Based on this, the article defends the hypothesis that Slovakia 1939-1945 was a de facto State.

This topic is not well-known, so the article contains a brief description of the historical facts on which the concepts of de iure and de facto State are applied. The issue of international recognition of Slovakia is connected to the problem of continuity of Czechoslovakia and the possible nullity of the Munich Agreement.

The article is structured in accordance with the factors influencing the main question: Was the Slovak State a de iure State or only a de facto State? These factors are:

1. Validity of the Munich Agreement,

2. Nature of the new Slovak State,

3. Relations between Slovakia and the German Reich,

4. International recognition of Slovakia and

5. International recognition of the Czechoslovak government in exile.

Some aspects of the topic have been already approached by many scholars. The question of the continuity of Czechoslovakia was elaborated by prominent Czechoslovak scholars and 
politicians: Edward Táborský, ${ }^{2}$ Edvard Beneš, ${ }^{3}$ Jan Kuklík, ${ }^{4}$ Štefan Luby, ${ }^{5}$ Jozef Beňa ${ }^{6}$ and others. It attracted the attention of many foreign scholars. Among others, it is necessary to mention Quincy Wright, ${ }^{7}$ Hersh Lauterpacht, ${ }^{8}$ Paul Gugggenheim ${ }^{9}$ and Krystyna Marek, ${ }^{10}$

Regarding the application of concepts of de facto and the jure State, the article is based on the general principles of the Montevideo Convention and on the work of Scott Pegg on the issue of de facto States. ${ }^{11}$

\section{De iure and de facto States}

In order to clarify what is considered a de facto and a de iure State, several paragraphs are dedicated to this issue in this article.

With respect to the de iure States, we apply the declarative theory of statehood as it was codified by the Montevideo Convention on the Rights and Duties of States signed on the 26th December 1933 during the Seventh International Conference of American States. Since then the Convention is part of international customary public law. The first article of the Convention says: The State as a person of international law should possess the following qualifications:

1. A permanent population,

2. A defined territory,

3. Government and

4. Capacity to enter into relations with the other States.

These criteria are subject to a wide criticism, ${ }^{12}$ but we still consider them useful as to determine whether a political entity is a de iure State or not.

For de facto States, we can accept the six main criteria adopted by Scott Pegg and can derive from them a definition of a de facto State. ${ }^{13}$ A number of characteristics of de facto

\footnotetext{
${ }^{2}$ Taborsky, Edvard (1944): The Czechoslovak cause. An account of the problems of International law in relation to Czechoslovakia, London, H.F.\&S. Witherby Ltd., and Taborsky, Edvard (1942): "Munich, Vienna Arbitration and International Law", in Czechoslovak Yearbook on International Law, London, pp. 22 - 25.

${ }^{3}$ Beneš, Edvard (2004): Paměti - Od Mnichova k nové válce a k novému vítězství, Praha, Naše vojsko.

${ }^{4}$ Kuklík, Jan - Němeček, Jan - Šebek, Jan (2011): Dlouhé stíny Mnichova: Mnichovská dohoda očima signatář́u a jeji dopady na Československo, Praha, Auditorium, pp. 390.

${ }^{5}$ Luby, Štefan: "Kontinuita a nariadenie č. 1/1944 Sb. n. SNR", in Právny obzor, vol. 30, no. 1 (1947), pp. 142 177.

${ }^{6}$ Beňa, Jozef (2001): Vývoj slovenského právneho poriadku, Banská Bystrica, Iris.

${ }^{7}$ Wright, Q.: "The Munich settlement and international law", in American journal of international law, vol. 33, no. 12 (1939), pp. 12-32.

${ }^{8}$ Lauterpacht, Hersch (2012): Recognition in International Law, Cambridge, Cambridge University Press, pp. 504.

${ }^{9}$ Guggenheim, Paul (1949): "La validité et la nullité des actes juridiques internationaux", in Recueil des cours de l'Académie de droit international de La Haye, no. 77.

${ }^{10}$ Marek, Krystyna (1954): Identity and Continuity of States in Public International Law, Genova, Librairie E. Droz.

${ }^{11}$ Pegg, Scott (1998): International Society and the De Facto State, Aldershot, Ashgate, and in Pegg, Scott (2004): "From De Facto States to States-Within-States: Progress, Problems, and Prospects", in Kingston, Paul; Spears, Ian (eds.): States Within States: Incipient Political Entities in the Post-Cold War Era, Palgrave Macmillan, pp. 35-46.

${ }^{12}$ (2012) The Max Planck Encyklopedia of Public International Law, Volume IX, Oxford, Oxford University Press, p. 475 and subsequent.
} 
States is included in article 1 of the 1933 Montevideo Convention on Rights and Duties of States ${ }^{14}$ :

1. There is an organized political leadership which receives some form of popular support,

2. This leadership has achieved sufficient capacity to provide governance or governmental services to a defined population,

3. A de facto State effectively controls its territory or the large majority of it for at least two years. ${ }^{15}$ These entities have some degree of permanence,

4. A de facto State views itself as capable of entering into relations with other States,

5. A de facto State actively seeks widespread international recognition of its sovereignty,

6. A de facto State is unable to achieve widespread recognition of its sovereignty and remains largely or totally unrecognized by the international society of sovereign States. ${ }^{16}$

Focusing on Slovakia 1939 - 1945, we will apply the concepts of de iure State and de facto State to determine the nature and character of this entity.

\section{The Czechoslovak Republic}

The Czechoslovak State was established on the 28th October 1918 when the National Committee in Prague formally announced the birth of the new state and published the law $\mathrm{n}$. 11/1918 Coll. as the legal base of the State.

In parallel the Slovak National Council gathered on the 30th October 1918 in Martin, declaring itself the only representative of Slovaks and approving the Declaration of the Slovak Nation, which stated its right for self-determination and declared that the Slovak nation was a part of Czechoslovak nation.

The new State and the new legal order was based on a revolutionary legitimacy, the right of the Czechoslovak nation to self-determination, and thus, on the sovereignty of the Czechoslovak people. Two institutions were declared entitled to talk on behalf of the people: The Slovak National Council spoke only on behalf of the Hungarian branch of the Czechoslovak nation (Slovaks) and the National Committee on behalf of the whole nation. This double declaration shows the non-existence of a single ethnical nation in Czechoslovakia. Elites of both nations agreed to present a united national front on the international scene because of the construction of the right to self-determination and in order to present a more effective position during post-war negotiations.

\footnotetext{
${ }^{13}$ There are disagreements around the edges of the definition but a reasonably broad consensus on what the basic elements of the definition should be.

${ }^{14}$ Pegg, Scott: "The Impact of De Facto States on International Law and the International Community". Presented on the conference Opening the World Order to de facto States - Limits and Potentialities for de facto States in the International Order, Brussels (15th May 2008), available in http://unpo.org/images/professor\%20scott\%20pegg.pdf.

${ }^{15}$ The figure is an arbitrary one. It may vary from case to case, but it reflects State of some kind of permanency in state existence.

${ }^{16}$ Whereas many currently recognized sovereign States have never effectively controlled their territories or delivered governmental services to their populations, they are recognized as sovereign States no matter how weak or ineffective they are. The de facto State, on the other hand, remains unrecognized no matter how effective its governance capabilities or how long it has actually controlled the territory it claims to rule.
} 
Agreement between representatives of both nations abroad was a necessary condition for the establishment of the new State. According to the agreements subscribed, the Slovak nation was to obtain self-government. But the interpretation of the agreements varied and Czechoslovakia was created as the unitary State of the single Czechoslovak nation, based on the Constitution of 1920. In practice, this nation did not exist and this later caused significant political problems. In Czechoslovakia, there were two big minorities: more than 3 million of Germans and almost 1 million of Hungarians. Hungarians and Germans were part of the titular nations of the dissolved monarchy. Therefore, there were deep secessionistic tendencies among them, which weakened Czechoslovakia from inside. The problem of tense inter-ethnic relations within the Czechoslovak nation in combination with the support by neighbouring countries to secessionist minorities, would partly cause the sad events of $1938-1939$.

\section{The Munich Agreement}

In order to understand the further development and conceptions regarding the continuity of the Czechoslovak State, it is important to deal in depth with the Munich Agreement, its origin, its validity or nullity from the perspective of the signatory countries or other powers and the arguments of the Czechoslovak government in exile during WWII, which linked the nullity of the Munich Agreement with the inviolability of the Czechoslovak borders and considered every legal and political development in Czechoslovakia after the 30th September 1938 as invalid.

The events which followed the Munich Agreement are very well known. It is not necessary to discuss them from the perspective of politics or morality. More important for us, is to examine its validity from the perspective of the international public law, since this was subject to doubts from the very beginning in some academic works of Q. Wright ${ }^{17}$ or E. Taborsky. ${ }^{18}$ The nullity in origin of the Munich Agreement was the political cornerstone of the Czechoslovak government in exile and a key concept in Czechoslovak constitutional law. On the other hand, P. Guggenheim, one of the leading scientific figures of international public law in this period, stated that the Munich Agreement was valid in its inception and only became void and null later on, as a result of events that happened in March of 1939. ${ }^{19}$

When we talk about the Munich Agreement, we need to understand that the declaration of the Czechoslovak constitution that defined Czechoslovakia as the national State of the Czechoslovak nation was a fiction. Czechoslovakia was a State that included several nations and many minorities: Czechs, Slovaks, Ruthenians, Hungarians, Germans, Poles, Romanians, Croats, Jews and others. Complicated relations between nations and minorities in the Republic made Czechoslovakia fragile from an international perspective. For more than twenty years of its existence since 1918, the Czechoslovak State did not adopt any substantial constitutional change to satisfy the nations and minorities of the Republic in order to strengthen the State. This lack of changes and other factors led to the radicalisations of some minorities and nations in Czechoslovakia, an element which was later used to deprive Czechoslovakia of part of its territory first and to finally put an end to its existence.

This best known ethnic clash is that involving the German minority. Disagreements between representatives of the Czechoslovak Germans supported by the German Reich and the Czechoslovak government became a sensitive international problem. In August and

\footnotetext{
${ }^{17}$ Wright, op. cit., pp. 12-32.

${ }^{18}$ Taborsky, "The Czechoslovak cause", op. cit., pp. $22-25$.

${ }^{19}$ Guggenheim, op. cit., p. 212.
} 
September of 1938 there were negotiations among Czechoslovakia, the German Reich, France and Great Britain in order to find a solution and to avoid war. In the second half of September, the governments of France and Great Britain informed the Czechoslovak government of their decision to support the German demands for the transfer of the Czechoslovak territory inhabited by Germans to Germany. The Czechoslovak government accepted this demand on the 21th September 1938. In the upcoming days, the Czechoslovak government resigned and the Czechoslovak army was mobilised. On the 29th September 1939, representatives of Germany, Italy, France and Great Britain met in Munich to discuss the Czechoslovak crisis. German's demands had grown since the 21th September 1938, but finally, the four powers reached an agreement based on the accords made before the 21th September 1938 and which were accepted by the Czechoslovak government.

The Czechoslovak minister of foreign affairs, Kamil Krofta, on the 30th September 1938, in presence of representatives of France, Italy and Great Britain, declared the agreement of his government with the settlement reached in Munich: "...in the name of the President of the Republic and in the name of the Czechoslovak government we accept the decisions taken in Munich without us and against us".20

Subsequently, Czechoslovakia appointed its representative to the International Committee and the German-Czechoslovak Committee, created according to the Article 3 of the Munich Agreement. On the 20th October, Germany and Czechoslovakia concluded an agreement for the settlement of the nationality question as the execution of the Agreement.

On the 2nd November 1938, the Vienna Arbitration took place. It meant that Czechoslovakia would have to transfer a significant portion of Slovakia and Ruthenia to Hungary.

Meanwhile, president Beneš resigned from his Office and left for exile. The National Assembly accorded an autonomous status to Slovakia and Ruthenia, a new president, Emil Hácha, was elected and the country was renamed as Czecho-Slovakia.

Later on, during WWII, exiled representatives of Czechoslovakia around Edvard Beneš, formulated the concept of the nullity of the Munich Agreement, supported the legal continuity of the Czechoslovak Republic and consequently the nullity of all events that happened after the 30th September 1938.

Edvard Beneš argued that the consent of the government to the Agreement was illegal and, as a consequence, the Agreement was not valid because:

1. The government did not have the constitutional right to agree with the cession of the State territory, only the National Assembly had the right;

2. The government accepted the proposals of Great Britain and France under the condition that there would be no further German demands and this condition was not fulfilled;

3. The government requested to be part of the negotiations on the cession conditions, but it was not the case;

4. The consent to the agreement was made under duress;

5. It was regarded as res inter alios acta. ${ }^{21}$

\footnotetext{
${ }^{20}$ Taborsky, "The Czechoslovak cause", op. cit., p. 25.

${ }^{21}$ Sivák, Florian (1998): Slovenské a české dejiny štátu a práva v rokoch 1918-1945, Bratislava, Univerzita Komenského, pp. 134-137.
} 
Of course, the first two arguments are based on the Czechoslovak constitutional law and have no significance in international law. The third one has no relevance. The Czechoslovak government simply could not push through its position. That acceptance was made under duress is obvious, but according to general international law, duress does not invalidate an agreement. $^{22}$

Besides, it was argued that the Munich Agreement was in contradiction with the Pact of the League of Nations, the Locarno Treaties of 1925 (obligation of peaceful solution of conflicts) and the so called Briand-Kellog Pact of 1928 (prohibition of using force to settle conflicts) ${ }^{23}$ putting it thus, in conflict with international law.

According to the Czechoslovak theory of Czechoslovak continuity, on the 30th September 1938, Czechoslovakia entered a time of lack of freedom and since then, all legal acts are invalid. It means that the resignation of president Beneš, the creation of the Slovak autonomy and other constitutional changes, as well as the establishment of an independent Slovakia and the Protectorate of Czechia and Moravia were void and null.

This theory was constructed after the events of 1938-1939 and played no role at the time. The theory lacks causality between the Munich Agreement and the starting date of the "time of un-freedom" on the 30th September 1938. Part of the territory was occupied on the beginning of October 1938, but the majority of the State territory remained under the Czechoslovak control. The theory argued that all these events were unconstitutional, but according to the Czechoslovak Constitution of 1920, only the Constitutional court could declare that. There was no constitutional declaration and thereby we need to maintain the legal fiction of constitutionality of all internal changes which took place in Czechoslovakia between the 30th September 1938 and the 15th March 1939.

Nevertheless, this concept became crucial for the Czechoslovak government in exile led by Mr. Beneš.

Signatory countries declared the invalidity of the Munich Agreement during the WWII years. The most interesting example was the repudiation of Great Britain done by $\mathrm{Mr}$. Anthony Eden on the 5th August 1942. We agree with Charles Pergler ${ }^{24}$ that the most important part of the correspondence ${ }^{25}$ lies in this declaration: "... as Germany has deliberately destroyed the arrangements concerning Czechoslovakia reached in 1938, in which His Majesty's government in the United Kingdom participated, His Majesty's government regard themselves as free from any engagements in this respect. At the final settlement of the Czechoslovak frontiers to be reached at the end of the war they will not be influenced by any changes effected in and since 1938". It is necessary to note that Great Britain did not repudiate the Agreement because it was contrary to international law, international morality or so "but solely on the ground that the Munich fiat was destroyed by Germany". ${ }^{26} \mathrm{Mr}$. Eden letter failed to reject Munich in toto but moreover, it left the question of Czechoslovak borders and the future of Sudetenland opened. From the reply of Mr. Jan Masaryk dated on the 5th August 1942, ${ }^{27}$ the dissatisfaction of the Czechoslovak government in exile in London is clear. Mr. Masaryk wrote that the Czechoslovak government in exile maintain "...our

\footnotetext{
${ }^{22}$ See more in Marek, op.cit., p. 284.

${ }^{23}$ Gronský, Jan (2005): Komentované dokumenty k ústavním dějinám Československa I, Praha, Karolinum, p. 265.

${ }^{24}$ Pergler, Charles: "The Munich "repudiation", in The American Journal of International Law, vol. 37, no. 2 (1943), pp. $308-310$.

25 "Great Britain-Czechoslovakia", in The American Journal of International Law, Vol. 37, No. 1 (1943), Supplement: Official Documents, pp. 2-3.

${ }^{26}$ Pergler, op.cit., p. 309.

27 "Great Britain-Czechoslovakia", op. cit., p. 3.
} 
political and juridical position with regard to the Munich Agreement and the events which followed...".

The position of the French national Committee was expressed in a letter signed by $\mathrm{Ch}$. de Gaulle and M. Dejean dated on the 29th September 1942 and addressed to Msgr. Šrámek, Prime Minister of Czechoslovak government in exile in London. The French document rejects the Munich Agreement stating "... in this spirit the French National Committee, rejecting the agreement signed in Munich on September 29, 1938, solemnly declare that they consider these agreements as null and void as also all acts accomplished in the application or in consequence of these same agreements. Recognising no territorial alterations affecting Czechoslovakia, supervening in 1938 or since that time, they undertake to do everything in their power to insure that the Czechoslovak Republic within frontiers prior to September, 1938, obtains all effective guarantees for her military and economic security, her territorial integrity, and her political unity". ${ }^{28}$

Charles de Gaulle did what Mr. Eden failed to do - to guarantee Czechoslovak preMunich frontiers. What de Gaulle meant by words "all acts accomplished in the application or in consequence of these same agreements" and by "political unity" is not clear. If it was said in relation to the internal Czechoslovak affairs after Munich and before the March days of 1939, it means something absolutely new for the international law of this time because heretofore this was purely an internal affair of Czechoslovakia.

The US never recognised the Munich Agreement and the Soviet Union repudiated the Agreement in the Czechoslovak-Soviet Treaty of 1943.

We cannot conclude that the Munich Agreement was null and void from its inception or that it was originally valid and just the events of March 1939 made it invalid, but it is necessary to follow the subsequent legal events to determine the essence and political character of Slovakia 1939-1945.

\section{Establishment of the Protectorate of Czechia and Moravia and the Slovak State}

Based on the new constitutional changes, Slovakia was granted an autonomous status in autumn 1938. In December 1938, the election to the Slovak Autonomy Diet took place and president Hácha appointed a Slovak autonomous government led by Mr. J. Tiso.

The international situation of Czecho-Slovakia has not improved since the acceptance of the Munich Agreement. France and Great Britain guaranteed Czechoslovak frontiers, but Germany postponed the guarantees and defined them as preliminary. ${ }^{29}$

Rebuilding of Czechoslovakia on a federal base did not end the conflicts between Czechs and Slovaks. There was deep mistrust among their representatives. This mistrust was supported and strengthened by the German Reich. Some radicals on the Slovak political scene called for full-fledged independence of Slovakia. In this atmosphere, president Hácha removed the Slovak government form its office and called the army to bring order to Slovakia. In a few days the ex-Prime Minister, J. Tiso, was invited by Adolf Hitler to Berlin. Hitler and Ribbentrop informed him on a crucial event, the deployment and progress of

\footnotetext{
${ }^{28}$ The Inter-Allies Review, Oct. 15, 1934.

${ }^{29}$ Petruf, Pavol (2011): Zahraničná politika Slovenskej republiky 1939-1945, Bratislava, Historický ústav SAV, p. 151 .
} 
Hungarian armies and the direct threat that the division of Slovakia among its neighbours would imply. The next day, on the 14th March 1939 Tiso presented this situation in the front of the Slovak Diet, which subsequently declared the independence of the State. ${ }^{30}$

On these events we have a lot of information from archives or from memoires of key players. Based on these sources we can State that the Slovak representatives were slowly moving towards more independence from the central Czechoslovak government but without outside interference the road to national independence would have been longer and the events of 14 March 1939 would not have happened. From this perspective it is necessary to say that the March events in Slovakia were orchestrated by Germans and Slovak key politicians that opted for national independence based on a geopolitical situation created by the German Reich in Central Europe.

The birth of the Slovak State gives rise to several questions in international law:

1. A realistic consideration of the events accompanying the formation of the new State can lead only to the conclusion that the new State owes its creation almost exclusively to the action of Germany.

2. The international status of Slovakia, at the moment of its establishment was especially affected by its relationship with Germany. The Agreement on the Protective Relation between the German Reich and the Slovak State was signed on the 18th and 23th of March 1939 and was to last for twenty-five years, provided that "Germany shall protect the political independence and territorial integrity of Slovakia" (Art. 1). This treaty further provides that for the execution of that protection, German armed forces might be stationed in certain zones of the Slovakia, where they would enjoy special privileges and might establish military infrastructures (Art. 2); and that the Slovak government would organise its own military forces in close cooperation with the German government (Art. 3). Corresponding to the relationship of protection agreed upon, the Slovak government will conduct its policy in close cooperation with the German government (Art. 4).

On the 15th March 1939, president Hácha was summoned to Berlin. After the meeting a communiqué was published ${ }^{31}$ in which we can read that president Hácha demanded Adolf Hitler to protect the Czech nation in order to achieve peace and order. Adolf Hitler accepted this requirement and expressed his will to protect the Czech nation and to guarantee its autonomous development.

\section{The International Recognition of Slovakia}

March events in Czecho-Slovakia created a wide disagreement in the international community. Great Britain and France as signatory countries of the Munich Agreement reacted with outrage on this development. Lord Halifax described the proceedings as an "arbitrary suppression of an independent sovereign State by force and a "violation of what I must regard as the elementary rules of international conduct". 32

Both countries sent protest notes to Germany, where they declared the events dated on the 15th March 1939 and the use of German military forces in the Czecho-Slovak soil unacceptable and in conflict with provisions and the spirit of the Munich Agreement. The

\footnotetext{
${ }^{30}$ See more on this Teich, Mikuláš; Kováč, Dušan; Brown, Martin D. (2011): Slovakia in History, Cambridge, Cambridge University Press, 2011, pp. 173 - 180.

31 "Czechoslovak Yearbook", op.cit., p. 223.

${ }^{32}$ Ibid, p. 13.
} 
role of Germany was described as contradicting to international law and the above mentioned countries refused to recognise territorial changes that occurred in the Czecho-Slovak territory. ${ }^{33}$

The main point of disagreement was the creation of the Protectorate on the 15th March 1939. The French note explicitly stated the event of the 15th March 1939, which France considered as opposed to the Munich Agreement. France and Great Britain put aside any declaration of a Slovak State and this was never mentioned in official documents. The reason for this might stem from the consideration that the reduction of any State's territory does not modify the identity of the State in question. Similarly, after the Munich Agreement, Czechoslovakia continued to exist and its international status was not diminished. But the act of the 15th March 1939 violated the Munich Agreement and inexorably led to the final extinction of Czechoslovakia, as a Czechoslovak State was no longer viable without Slovakia.

The Soviet commissar for international affairs, M. Litvinov, condemned from his part both the creation of the Protectorate, and the establishment of the Slovak State, as well as the occupation of Ruthenia by Hungary. ${ }^{34}$ Similarly, the US government challenged the German conduct:

"This Government (...) cannot refrain from making known this country's condemnation of the acts which have resulted in the temporary extinguishment of a free and independent State and people". ${ }^{35}$

We can note that a substantial part of the international community refused to recognise the March events in Czechoslovakia and the consequences resulting from it. This was reflected in the persistence of the Czechoslovak legations in many countries. In these countries, Czechoslovak representatives were allowed to maintain their status and to develop their activity to re-establish Czechoslovakia.

However, after two months, the attitude of some governments, including those of some great powers, started to change.

Great Britain asked for a new exequatur for its consul Peter Pares and the UK therefore de facto recognised Slovakia on the 4th May 1939. De facto recognition by France followed on the 14th July 1939. Both great powers opened legations in the Slovak capital Bratislava. Still, Czechoslovak Legations in London and Paris remained active.

Despite its previous position, the USSR also recognised Slovakia on the 17th September 1939, accepting an Slovak Minister to Moscow and closing the Czechoslovak Legation. ${ }^{36}$

Slovakia was recognised either de iure or de facto by a total of 27 States. ${ }^{37}$

Recognition of the independent Slovakia implied the automatic recognition of the extinction of Czechoslovakia as an independent State. This was manifested by the closure of the Czechoslovak legations in some countries recognising Slovakia, i.e. Switzerland and Soviet Union.

The US remained consistent in their initial approach, as they never recognised the Munich Agreement, the extinction of Czechoslovakia or any territorial changes made to Czechoslovak territory in the period $1938-1939 .^{38}$

\footnotetext{
${ }^{33}$ Marek, op.cit., p. 287.

34 "Czechoslovak Yearbook", op. cit., pp. 23-25.

${ }^{35}$ Ibid, p. 20.

${ }^{36}$ Marek, op. cit., p. 289.

${ }^{37}$ For more information see Petruf, op.cit.
} 
The approach of the international organisations to the extinction of the Czechoslovak State and the establishment of an independent Slovakia was mixed. While the League of Nations ${ }^{39}$ and the International Labour Union ${ }^{40}$ maintained Czechoslovakia as one of its members, the Universal Postal Union ${ }^{41}$ recognised both Slovakia as an independent member and the protectorate as part of the German Reich,the International Telecommunication Union $^{42}$ drew on a mixed responses, admitted as members both Slovakia and the former Czechoslovakia, while assuming the notification by the German Reich that Czechoslovakia was not member of the Union anymore.

The situation changed after the attack on Poland perpetrated on the 1st September 1939 by the German Reich: The German military forces not only used the Slovak territory to attack Poland from the south, but they were supported by small units of the Slovak army, with the goal to recapture the territories lost in 1934, 1938 and 1939.

By the 1st September 1939, legations of Poland, France and Great Britain were closed in Bratislava. Closure of the legations was carried out by Slovak officials, but with the assistance from the German military. ${ }^{43}$ Thus, the 1st September 1939 marked the onset of a new phase in relations between Slovakia and the western powers.

The starting position by the British could be described by the words of under-secretary R. A. Butler pronounced during the debate in the House of Commons on the 9th October 1939:

\begin{abstract}
"His Majesty's Government obtained an exequatur for a Consul in Bratislava in May last, thereby according de facto recognition to the Slovak Government. His Majesty's Government subsequently granted an exequatur to a Slovak Consul in London. During August the German Government extended their military control over the whole of Slovakia and, on 2nd September, His Majesty's Consulate at Bratislava was closed. On 8 th September Slovakia was proclaimed to be territory in enemy occupation. The Slovak Consul in London has protested against the occupation of his country by German forces and has declared the aims and ideals of His Majesty's Government and France to be identical with those of the Slovak people. His Majesty's Government continue to recognise him as the Slovak representative in London".
\end{abstract}

In spite of doubts by the UK government on the very onset (March, April 1939) on the Slovak State's independence, Great Britain, by August 1939, at the latest, already considered Slovakia as a fully sovereign State. However, due to the presence of the German army on Slovak soil in the second part of August 1939, Slovakia was subsequently considered as an occupied State. This approach was supported by the declaration of the Slovak consul in London or the Slovak Ambassador in Warsaw, who both refused to return to Slovakia, declaring Slovakia as an occupied State.

\footnotetext{
${ }^{38}$ Slovakia's representatives made attempts to obtain U.S. recognition even later in 1940; U.S. State Department refused discussion this topic. See more in Teich et al., op.cit., p. 193.

${ }^{39}$ Langer, Robert (1947): Seizure the Territory, New Jersey, Princeton University Press, p. 221. Slovakia did not apply for membership in League of Nations and therefore League of Nations did not need to solve the question competing membership of Czechoslovakia and Slovakia.

${ }^{40}$ I.L.O. Yearbooks, $1938-1940$.

${ }^{41}$ Slovak ministry responsible for communication with international organisations informed Universal Postal Union already on the 6th March 1939 that stamps overprinted with words "Slovenský štát 1939" were issued, i.e. 8 days before Slovak Diet declared independance. Official application for Union membership was send on 6th April 1939 and accepted on the 25th April 1939. See more in Kreis, Georg (2013): Switzerland and the Second World War. London: Routledge, ftn. 19.

${ }^{42}$ International Telecommunication Union, Rapport de Gestion, 1940 - 1944.

${ }^{43}$ Petruf, op. cit., note 646.
} 
This turn of events did not affect the Slovak relations with other States, i.e. Soviet Union, Switzerland, Spain, Sweden among others. Diplomatic relations between Slovakia and those countries that did not participated in WWII, continued almost until the very end of the war. Only with the end of the war and the loss of control of all Slovak territory by the government of Bratislava after Germany was completely defeated, were diplomatic relations interrupted. $^{44}$

\section{Substance of Slovak-German Relations 1939-1945}

As mentioned above, German representatives had been playing a great geopolitical game in Central Europe and its result was an independent Slovakia. Adolf Hitler promised Jozef Tiso during his visit to Munich on the 13th March 1939, the protection of Slovakia against Poland and especially against Hungary, which threatened the sole existence of Slovakia.

The Agreement on the Protective Relations between the German Reich and the Slovak State was signed on the 18th March 1939 by Slovak representatives and on the 23rd March by their German counterpart. It came into effect immediately after the signature by both sides. ${ }^{45}$

Based on the Agreement, the Reich pledged to protect the independence and the territorial integrity of the Slovak State, while Slovakia agreed on the establishment of German military bases in the western part of its territory along with the prevalence of German jurisdiction above Slovak citizens in this territory. Slovakia was obliged to align both its military forces and its diplomacy in narrow concord with the Reich.

The Protective Agreement is so explicit regarding relations between Slovakia and Germany, that we may consider Slovakia had become a de iure protectorate of Germany.

German interests in Slovakia were represented by its Legation, by representatives of the German national minority and by special advisers (berater) who were appointed in every important Slovak governmental Office. ${ }^{46}$

A good example of the German interference into Slovak internal affairs is the so called Salzburg negotiations that took place in 1940 between both Slovak and German governments. The Slovak ministers tried to develop relations with western powers and to maintain the neutrality of Slovakia during the war. These pretensions were dismissed, while the Slovak political scene was replaced with German allies. Since then, Slovakia remained a loyal satellite of the Reich until the very end of the war.

In the second half of the year 1944, German troops were invited to solve security problems in Slovakia by way of crashing the uprising of the main part of the Slovak army, whose representatives tried to escape the prospect of the impending German defeat and switch sides with the allies. German troops defeated the Slovak army's uprising and stayed on Slovak territory until their defeat by the invading Soviet and Romanian armies at the beginning of 1945. The Slovak government based in Bratislava definitely lost control of its territory by late August 1944.

\footnotetext{
${ }^{44}$ Special case in interrupting diplomatic relations with Slovakia is Spain. For instance, Sweden and Switzerland interrupted diplomatic relations due to renewal relations with Czechoslovakia, but Spain interrupted relations with Slovakia on 18th April 1945, but Slovak Ambassador in Madrid could retain his immunities and Slovak embassy in Madrid kept semi-diplomatic status until late fifties.

45 According to Slovak law, any international treaty should be published in official law collection in order to become valid. The Agreement was not published until second half of 1940. The issue was simply too sensitive politically in Slovakia. The Agreement did not help Slovakia during undeclared war with Hungary in March 1939. German Reich abandoned its ally and Slovakia lost further territory.

${ }^{46}$ Hoensch, Jörg K. (2001): Slovensko a Hitlerova východná politika, Bratislava, VEDA, pp. 202-203.
} 
In the light of this, there is no doubt that the allegedly independent Slovak State was in fact a German puppet State created by German Reich on the corresponding part of the Czechoslovak territory. No amount of recognition by any third State could invested it with a character of independent State. ${ }^{47}$

Seen form a political point of view and in historical perspective, all these events, beginning with the Munich Agreement, form a logical whole and represent successive steps taken with the goal of the final destruction of the Czechoslovak State, with the creation of new entities on its territory.

Legally, though, they must be clearly distinguished. It is at least dubious whether the Munich Agreement was originally null and void. Many arguments claim otherwise. However, no shadow of legality can be claimed for the events of March 1939. On the contrary, by its aggression against Czechoslovakia, Germany violated the fundamental obligations under international law, to respect the sovereignty and territorial integrity of another State. More particularly, Germany violated the Briand-Kellogg Pact, the German-Czechoslovak Arbitration Treaty of 1926 and the Munich Agreement itself.

Leaving aside the discussion whether the Munich Agreement was void and null or not, the identity of Czechoslovakia was not affected by it, it was affected only by events of March 1939.

\section{Czechoslovakia as Subject of International Law during WWII}

Since March 1939 until the outbreak of WWII, there was no active sign of the existence of Czechoslovakia, if not by the presence of some Czechoslovak legations. These legations operated under no central co-ordinating centre and had no State to represent.

The outbreak of the WWII brought about a short-lived revival of one sign of Czechoslovakia's existence, with the formation of Czechoslovak Legions in Poland.

The first strictly legal sign of the continuing existence of Czechoslovakia, was very unorthodox indeed. On the 2nd October 1939, the French Prime Minister Daladier, signed an agreement with the Czechoslovak Minister to France, Štefan Osuský, on the establishment of an autonomous Czechoslovak army on the French soil. Š. Osuský acted as agent of the nonexisting Provisional government of Czechoslovakia. ${ }^{48}$ This situation can be compared to that during WWI, when France signed such agreements with national committees and these committees were recognised as belligerents. However, in this case, no Provisional government actually existed. This situation was rectified only in November 1939, when a Czechoslovak National Committee was set up in Paris and Š. Osuský notified the French government that the Committee would step in to fulfil all obligations arousing from the agreement.

Even the legal nature of this body is very curious. Besides Mr. Osuský, the body exclusively contained private citizens. The Committee did not declare itself as a State organ or claimed even to represent the Czechoslovak State. It simply declared to represent Czechoslovak peoples. From the point of view of international Czechoslovak constitutional law, the Committee was a private organisation.

Despite the recognition of the Czechoslovak army on the French soil, recognition of the Committee was limited. Following the French defeat in 1940, the Committee moved to

\footnotetext{
${ }^{47}$ Marek, op. cit., p. 291.

48 Taborsky, "The Czechoslovak cause", op.cit., p. 68.
} 
London where it adopted a new name: the Provisional government. Henceforth, the Provisional government claimed to be government in exile created according to the Czechoslovak constitution of 1920. As it was impossible to follow all provisions of the said constitution, it was declared that the constitution would be valid during the time of exile only as a legal principle. From a strictly legal point of view, we can state that the Provisional government started building its own constitutional law when it claimed a relation to the constitution of 1920 in the sense of its constitutional values and principles. This means the link to the constitution of 1920 was very weak and vague, and there was therefore no body to determine whether the Provisional government really operated within the frame of the constitutional principles and values.

What enabled this situation was the fact that Slovakia joined the war on the side of Germany, which led to the subsequent interruption of diplomatic relations between Slovakia and all States waging war against Germany. This had the logical result of the international recognition of the Czechoslovak government in exile by these States.

The Czechoslovak government in exile was thus recognised by Great Britain on the 21st July 1940, by the USSR on the 18th July 1941 and by the US on the 26th October 1942. ${ }^{49}$

Despite the recognition of the Czechoslovak government in exile by Great Britain, the distinction between the Czechoslovak government and other constitutional governments ${ }^{50}$ functioning on British soil was maintained. The Czechoslovak government was considered as an organ sui generis, but not as the organ of an existing State. ${ }^{51}$

After the outbreak of war between the Soviet Union and Germany in 1941, the Czechoslovak government in exile began negotiations with representatives of the USSR and soon concluded the Czechoslovak-Soviet treaties, where the full continuity of the Czechoslovak State was recognised. This happened despite the fact, that the Soviet Union had closed legation of Czechoslovakia in autumn 1939 and opened its embassy in the Slovak Bratislava.

The British government provided on the 12th November 1940 full recognition to the Czechoslovak government. Since then, the status of this government was the same as that of the constitutional governments of Poland or Yugoslavia.

The recognition of the government in exile was not connected with the repudiation of the Munich Agreement. During the war time, these two questions remained separated. Of course, this approach by Great Britain was a potential source of problems for the government in exile, since none of its members held a high position in the former Czechoslovak government before the 15th March 1939, so both the legitimacy and legality of this government in exile could be easily challenged. The major part of all Czechoslovak diplomatic efforts during the WWII were invested in persuading allied governments to recognise the legal nullity of all acts concerning Czechoslovakia after the 30th September 1938.52

\footnotetext{
${ }^{49}$ Rychlík, Jan (1998): Češi a Slováci ve 20. století I, Praha, Vyšehrad, pp. 219-220 and 224.

${ }^{50}$ I.e. Polish or Yugoslav governments in exile.

${ }^{51}$ Marek, op. cit., p. 315.

${ }^{52}$ Legitimacy of Czechoslovak government in exile was derived from presidential office of Mr. Beneš, but he stepped down as Czechoslovak president on 5th October 1938 and new president Mr. Hácha was subsequently elected by National Assembly. Therefore the concept of Czechoslovak continuity was crucial not only for the State itself, but for its representatives as well. If the concept were not widely recognised or at least were challenged, position of Czechoslovak exile government would be in trouble in relation to its partners and creditors.
} 
The international position of Czechoslovakia was confirmed by the Treaty on friendship, cooperation and after-war mutual support signed with the Soviet Union on the 12th December 1943 in Moscow and the Treaty between Czechoslovakia and Soviet Union on administration of liberated territories, signed on the 8th May 1944.

Based on the decision at the Yalta Conference, Czechoslovakia belonged to ally countries along with Poland and Yugoslavia. Hungary, Romania and Bulgaria were counted as defeated States.

The short description above of the legal and diplomatic developments regarding the recognition of Slovakia, the Czechoslovak government in exile, the continuity of Czechoslovakia and the repudiation of the Munich Agreement, sums up the situation concerning the issues of recognition and survival of small States in turbulent times which might happen again in the future.

Slovakia, despite outrage by the international community in March 1939 after Germany had violated basic principles of international law as well as its own obligations to third parties, gradually obtained de facto, if not de iure recognition from 29 Stat with the exception of the US. The situation of Czechoslovak legations was critical in summer 1939, as there was no Czechoslovak State and no co-ordinating body, while the Slovak State/Slovak Republic had already obtained widespread recognition. Even the Protectorate of Czechia and Moravia was the facto recognised as part of the Reich. The Slovak diplomacy seemed to have triumphed over Czechoslovak legations.

The situation, however, started to gradually change after the outbreak of WWII and the Slovak entry into the war on the side of Germany. Czechoslovaks abroad, as mere private citizens, had to undertake many efforts in order to reach recognition, first as a sui generis organ and later as the Provisional government of the Czechoslovak Republic. Within few years, the approach to Czechoslovak statehood of both western powers and the Soviet Union, changed significantly twice. During all those years, hardly anything important happened in the territory of Czechoslovakia. The organs of both the Protectorate and the Slovak State/Slovak Republic kept functioning. The shift occurred in the perception of powers regarding the arrangement in Central Europe. The diligent work by Czechoslovaks abroad and the turbulent war situation caused that decisions made in 1938 and 1939 were revoked and unorthodox steps adopted to amend its consequences.

\section{Slovakia: de facto or de iure State?}

In adopting the usual declarative theory of statehood, we need to apply the 4 Montevideo criteria on Slovakia 1939 - 1945: 1. A permanent population, 2. A defined territory, 3. A government and 4. A capacity to enter into relations with the other States.

We are sure that Slovakia possessed permanent population and defined territory since the declaration of independence until the uprising of part of its army in summer 1944. Once the uprising was crashed and Slovakia was occupied by the German army, the government in Bratislava could not administer the country effectively.

As for the two other criteria, it is more problematic. Slovakia was ruled by the Slovak government relatively freely, but it was based on the protective agreement of Germany, where German representatives were appointed to governmental offices. This does not mean that these "advisers" ruled the country, but manoeuvring space of Slovak organs was limited. The best example of the level if dependence of Slovak officials on their German protectors, was 
the so-called Salzburg negotiation of 1940, which from a real negotiation, was a diktat to the Slovak government.

The fourth criterion, the capacity to enter into relations with the other States was at first sight unproblematic. Slovakia was widely recognised, its legations were established in many States and many international treaties were signed with other States, while Slovakia was a State member of several respected international organisations. From formal point of view, Slovakia thus possessed full capacity to maintain diplomatic relations. However, if we explore deeper relations of Slovakia to other States, we need again to consider the Protective agreement with Germany. A range of diplomatic activities was limited by the German interests; one of the ministers who was dismissed as a result of the process of Salzburg, was the Minister of foreign affairs, F. Durčanský, who was aiming to communicate with western powers.

Based on this short enumeration, we can conclude that Slovakia was not a de iure State, with its statehood was limited by German protection. This could have changed with the weakening of Germany, but in this process, Slovakia did not survive and its territory became part of "reborn" Czechoslovakia.

For de facto States we adopted criteria by S. Pegg: ${ }^{.3}$

1. There is an organized political leadership which receives some form of popular support,

2. This leadership has achieved sufficient capacity to provide governance or governmental services to a defined population,

3. The de facto State effectively controls its territory or the large majority of it for at least two years. These entities have some degree of permanence,

4. The de facto State views itself as capable of entering into relations with other States,

5. The de facto State actively seeks widespread international recognition of its sovereignty,

6. The de facto State is unable to achieve widespread recognition of its sovereignty and remains largely or totally unrecognized by the international society of sovereign States.

From the criteria above, only the sixth one is worth discussing. Slovakia has achieved widespread recognition, but if we assess the third criterion and consider the necessity to maintain control over territory at least for two years, we should extend this time criterion for all criteria or simply add a seventh criterion, which would be temporal criterion, as all other criteria need to be fulfilled for at least two years. Thought in this way, Slovakia from 1939 to 1945 got widespread recognition in the period of May - June 1939, but started to lose it in September 1939. By mid-1940, Slovakia had lost the crucial recognition of Great Britain as a consequence of the recognition of the Czechoslovak government in exile.

\section{Conclusion}

Slovakia was a de facto State which had a great potential to elevate itself to the status of $d e$ iure State. The achievement of such status was impeding by the weakening of its "protector", Germany. This weakening happened by the end of the WWII, Slovakia did not survive Germany's defeat and Czechoslovakia as re-established as a State.

\footnotetext{
${ }^{53}$ Pegg, "The Impact of De Facto", op. cit., p. 3.
} 
The Example of Slovakia in the period 1939 - 1945 is a warning for every small nation seeking independence. Smaller States are always more vulnerable in turbulent times, but new small States which obtained their independence against the will of their parent States, exist ipso facto in a hostile environment where they are even more vulnerable.

If Czechoslovakia had been capable to solve its internal problems during the period of relative international stability during the decades of the twenties and the beginning of the thirties of the past century, Czechoslovakia might have survived beginning of the war or at least could have withstood German treats much more effectively. A nation counting almost 15 million people, a big modern army and fortified borders was much more capable to defend itself, than a Czechoslovakia festered by ongoing internal disputes or a tiny Slovakia with only 3 million inhabitants. Smaller or fragile States are always the target of geopolitical games of their neighbours or big powers. Bigger States with settled internal affairs are less fragile and more stable. Even widespread recognition is not in itself a guarantee of a State' survival. 